\title{
Perancangan Sistem Informasi Eksekutif Tridharma Perguruan Tinggi Universitas Duta Bangsa Surakarta Dengan Service Oriented Architecture (SOA)
}

\author{
Khoirul Mustofa ${ }^{1)}$, M. Suyanto ${ }^{2)}$, Sudarmawan ${ }^{3)}$ \\ ${ }^{1}$ Universitas Duta Bangsa Surakarta, ${ }^{2,3}$ Universitas AMIKOM Yogyakarta \\ ${ }^{1}$ Jl. Bhayangkara No. 55-57 Tipes, Serengan, Surakarta, ${ }^{2,3} \mathrm{Jl}$. Ring Road Utara, Condong Catur, \\ Depok, Sleman, Yogyakarta \\ 1'mustofa.khoirul26@gmail.com, ${ }^{2}$ yanto@amikom.ac.id, ${ }^{3}$ sudarmawan@amikom.ac.id
}

\begin{abstract}
Abstrak
The design of the tri dharma college executive information system is used to assist in making decisions. The university tri dharma executive information system aims to determine the performance of lecturers in the implementation of tri dharma. Executive information system design and executive information system analysis are used in achieving research objectives. Information from the use of the executive information system produces a summary of the performance of lecturers in the implementation of the tri dharma.
\end{abstract}

Kata kunci:Design, executive information system, tri dharma.

\section{PENDAhUluAN}

Sistem informasi eksekutif merupakan alat yang digunakan untuk menyediakan informasi guna mendukung pengambilan keputusan (Bernadi \& Suharjito, 2016). Pengambilan keputusan diperlukan untuk mencapai tujuan. Tujuan individu atau organisasi (Anggadini, 2013). Sistem informasi eksekutif menyediakan informasi yang digunakan sebagai rekomendasi dalam mendukung pengambilan keputusan. Pengambilan keputusan merupakan aktifitas yang melibatkan manusia dan informasi dalam melakukan pemilihan tindakan alternatif dalam mencapai tujuan (Turban, Aronson, et al., 2007). Sistem informasi eksekutif merupakan alat untuk menentukan tujuan bisnis bagi organisasi, dengan melibatkan manusia dan informasi dan hasilnya berupa rekomendasi atau alternatif pilihan untuk diterapkan pada organisasi.

Sistem informasi eksekutif tridharma perguruan tinggi menggunakan banyak sumber informasi untuk mengolah informasi menjadi bermanfaat. Sistem informasi yang dimiliki oleh Universitas Duta Bangsa Surakarta saat ini yaitu sistem informasi akademik, sistem informasi kepegawaian, dan sistem informasi LPPM. Ketiga sistem informasi tersebut diintegrasikan dengan sistem informasi eksekutif tridharma dengan model Service Oriented Architecture (SOA) dengan melakukan ekstraksi pada sistem informamsi sumber. Data yang telah diekstrak lalu ditransformasikan sesuai dengan kebutuhan dan load (dimuat) pada sistem informasi eksekutif.

Pendidikan dalam tridharma merupakan usaha sadar dan terencana untuk mewujudkan proses belajar untuk mengembangkan potensi diri. Penelitian dalam tridharma merupakan kegiatan yang dilakukan sesuai kaidah dan metode ilmiah untuk memperoleh pengetahuan dan Pengabdian kepada Masyarakat merupakan kegiatan memanfaatkan ilmu pengetahuan untuk memajukan dan mensejahterakan masyarakat. Ketiga komponen ini merupakan wujud nyata civitas akademis khususnya dosen untuk mentransformasikan ilmu pengetahuan untuk mengembangkan potensi, mengembangkan ilmu pengetahuan dan menyebarluaskannya kepada masyarakat (Sutrisna Wibawa, 2017).

Dosen yang merupakan bagian dari organisasi perguruan tinggi, merupakan sebuah profesi pendidikan profesional yang dilindungi oleh Undang-undang No. 14 Tahun 2005 tentang Guru dan Dosen. Undangundang tersebut menuntut dosen untuk mengembangkan kompetensi. Dosen dengan kompetensi yang baik dimungkinkan memiliki jenjang karir yang baik. Penilaian karir dosen dosen diperlukan untuk mengetahui kinerja yang dimiliki oleh dosen (Rubiono \& Finahari, 2017). Penilaian kinerja dosen ini 
bertujuan untuk memperoleh karir dalam profesi dosen berupa jabatan fungsional.

Lembaga Layanan Pendidikan Tinggi Wilayah VI Jawa Tengah saat ini telah memiliki Sistem Informasi JAFA go Online atau SiJaGO (VI, 2019). Sistem Informasi ini pada umumnya bekerja dengan baik. Namun demikian, dari sisi internal organisasi perguruan tinggi menemui kesulitan untuk mengetahui dan menampilkan laporan rekam jejak dosen yang akan mengusulkan hingga yang telah memiliki jabatan fungsional.

Berdasarkan uraian tersebut diatas maka Perancangan Sistem Informasi Eksekutif Tridharma Perguruan Tinggi diperlukan guna mengetahui dan menampilkan rekam jejak dosen terutama pada pendidikan, penelitian dan pengabdian kepada masyarakat serta penunjang. Perancangan sistem informasi ini bertujuan untuk memudahkan pihak manajemen puncak secara komprehensif mengetahui kinerja perguruan tinggi dalam hal mewujudkan kualitas mutu organisasi pendidikan tinggi yang berdaya saing.

Siklus sistem informasi eksekutif merupakan tahapan pengembangan sistem. Tahapan pengembangan dilakukan berulang hingga mencapai tingkat yang sesuai dengan kebutuhan pengguna dalam hal ini perguruan tinggi. Sistem Informasi Eksekutif merupakan bagian dari intelijen bisnis yang bertujuan untuk menyediakan informasi pada manajemen tingkat puncak untuk mendukung proses bisnis yang dikelola. Sistem informasi Eksekutif atau Executive Information System selanjutnya disebut EIS (Lungu \& Bara, 2005) merupakan daur pengembangan sistem dengan enam tahapan yaitu: 1) justifikasi; 2) perencanaan; 3) analisis bisnis; 4) perancangan; 5) pengembangan dan 6) penerapan. Pemilihan metode pengembangan dengan siklus EIS, karena metode ini melibatkan pertimbangan perihal yang dibutuhkan dari sisi manajemen puncak dan dosen.

Berdasarkan masalah tersebut dapat diuraikan rumusan masalah sebagai berikut, yaitu: "Bagaimana merancang Sistem Informasi Eksekutif untuk menghasilkan keputusan strategi promosi jabatan fungsional bagi dosen Universitas Duta Bangsa Surakarta dengan Service Oriented Architecture?".

Tujuan penelitian ini yaitu merancang Sistem Informasi Eksekutif untuk menghasilkan keputusan strategi promosi jabatan fungsional bagi dosen Universitas Duta Bangsa Surakarta dengan Service Oriented Architecture.

Sisten Informasi Eksekutif adalah Sistem informasi yang penyajiannya melibatkan berbagai macam sumber dan menyediakan ringkasan penting bagi manajemen puncak (Bernadi, 2016). Fungsi sistem informasi eksekutif yaitu untuk melakukan pengambilan keputusan berdasarkan rekomendasi yang diberikan oleh sistem informasi yang digunakan (Putra, Gemilang, et al., 2019). Manfaat dari penggunaan sistem informasi eksekutif salah satunya yaitu menghasilkan rekomendasi berdasarkan pemrosesan data yang dilakukan. Hasilnya memudahkan dalam menyusun rumusan strategi bagi perguruan tinggi (Indriyani, 2019).

Tridharma merupakan wujud nyata perguruan tinggi dalam membantu pemerintah dalam mencerdasakan bangsa dengan kegiatan pendidikan, penelitian dan pengabdian kepada masyarakat serta kegiatan tridharma tersebut sesuai dengan Undang-undang No.12 Tahun 2012, Pasal 1 Ayat 9 (Sutrisna Wibawa, 2017). Kegiatan tridharma juga diatur dalam Peraturan Presiden No. 4 Tahun 2014 Republik Indonesia yang menjelaskan tri dharma merupakan bagian dari beban kerja dosen (Adiguna \& Muhajirin, 2017). Tri dharma sendiri merupakan indikator utama dalam mengukur kinerja mutu penyelenggaraan pendidikan perguruan tinggi (Heri Nurdiyanto \& Envermy Vem, 2015).

Service Oriented Architecture (SOA) adalah Pemodelan pengintegrasian sistem yang bertujuan untuk memberikan layanan bagi pengguna sistem meskipun penggunaan platform yang berbeda (Tarigan S, Soedjatmiko, et al., 2010). Pemodelan ini mengintegrasikan sistem informasi yang ada untuk memberikan layanan penggunaan sistem seolah-olah terpadu dengan memanfaatkan web service.

\section{METODE PENELITIAN}

Alur penelitian merupakan tahapan yang dilaksanakan untuk mencapai tujuan penelitian. Alur penelitian ini ditunjukan pada gambar 1 berikut ini: 


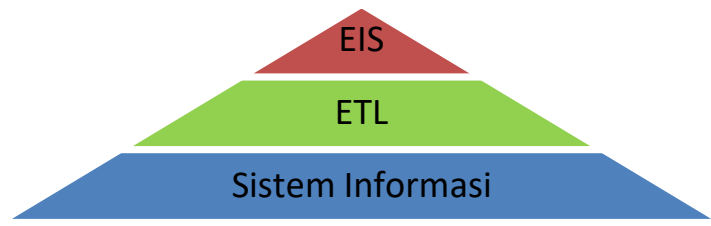

Gambar 1. Alur Penelitian

Sistem informasi Eksekutif merupakan suatu sistem informasi yang menampilkan rumusan strategi berdasarkan hasil proses ekstraksi load dan transform yang diperoleh dari sistem informasi yang dimiliki oleh universitas duta bangsa surakarta.

Sistem Informasi Kepegawaian, Sistem Informasi Akademik dan Sistem Informasi Lembaga Penelitian dan Pengabdian Masyarakat merupakan jenis sistem transaksional yang menyimpan riwayat penyelenggaraan tri dharma dosen.

Data yang diperoleh dari ketiga sistem informasi tersebut kemudian diproses dengan ektraksi, transform dan load untuk memperoleh informasi pendahuluan yang menggambarkan dosen yang dianggap telah memenuhi syarat dalam mengusulkan jabatan fungsional.

Hasil dari penerapan proses ekstraksi, transform dan load berupa ringkasan yang menggambarkan jumlah dosen yang direkomendasikan dalam mengusulkan jabatan fungsional.

\section{a. Service Oriented Architecture (SOA) Tridharma.}

Arsitektur berorientasi layanan yaitu sebuah teknik dalam melakukan perancangan sistem yang bertujuan untuk melakukan pengintegrasian data dari beberapa sumber sistem informasi. Arsitektur orientasi layanan sistem informasi eksekutif tridharma ditunjukan oleh gambar 2:

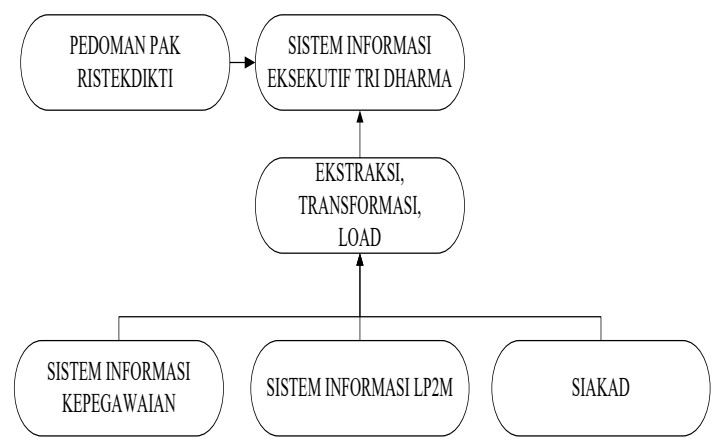

Gambar 2. SOA Tridharma

Perancangan sistem informasi eksekutif tridharma menggunakan SOA yang ditunjukan pada gambar tersebut menunjukan hubungan antar komponen Pedoman PAK Ristekdikti sebagai faktor eksternal antar sistem informasi kepegawaian, sistem informasi LPPM dan sistem informasi akademik sebagai dasar dalam menampilkan data pada sistem informasi eksekutif tridharma perguruan tinggi.

Informasi yang dihasilkan dari Sistem Informasi Eksekutif Tridharma berupa keputusan strategi dalam pengembangan sumberdaya manusia dalam hal ini Dosen sebagai pelaksanan tridharma.

Proses ETL dalam penelitian ini sebagai dasar dalam mendukung sistem pengambilan keputusan yaitu dengan mengambil informasi yang diperlukan dari sistem informasi kepegawain, sistem informasi akademik dan sistem informasi lembaga penelitian dan pengabdian masyarakat.

\section{b. Pedoman Penetapan Angka Kredit (PAK) Ristekdikti.}

Komponen penilaian dalam jabatan akademik dosen terdiri dari (i) unsur utama yang meliputi: pendidikan (meliputi pendidikan sekolah dan pelaksanaan pendidikan (pengajaran), penelitian (meliputi pelaksanaan penelitian dan menghasilkan karyailmiah sains/teknologi/seni/sastra), dan pengabdian kepada masyarakat dan (ii)unsur penunjang yang merupakan kegiatan pendukung pelaksanaan tugas pokokdosen.

Penilaian kegiatan yang dilakukan untuk usul pengangkatan pertama dankenaikan jabatan akademik dalam hal-hal tertentu diberlakukan batas maksimal yangdiakui pada komponen-komponen tertentu. Batas maksimal diberlakukan dengantujuan untuk mendistribusikan tugas pokok dan fungsi dosen pada setiap sub unsurkegiatan dalam satu unsur kegiatan maupun pendistribusian untuk masingmasingunsur dan pada strata pendidikan (diploma/sarjana, magister dan doktor). Dosen pengusul untukdapat menduduki jenjang jabatan akademik dan/atau pangkat tertentu, dosen wajibmemenuhi angka kredit kumulatif dengan distribusi unsur utama dan penunjangtertentu. Jumlah angka kredit untuk setiap unsur ditunjukan pada gambar tabel 1

Gambar Tabel 1 Jumlah Angka Kredit Kumulatif 


\begin{tabular}{|c|c|c|c|c|c|c|}
\hline \multirow[b]{2}{*}{$\begin{array}{l}\mathrm{N} \\
\mathrm{o}\end{array}$} & \multirow[b]{2}{*}{ Jabatan } & \multirow[b]{2}{*}{$\begin{array}{l}\text { Kualifikasi } \\
\text { Akademik }\end{array}$} & \multicolumn{3}{|c|}{ Unsur Utama } & \multirow[b]{2}{*}{$\begin{array}{c}\text { Unsur } \\
\text { Penuniang }\end{array}$} \\
\hline & & & $\begin{array}{l}\text { Pelaksanaan } \\
\text { Pendidikan }\end{array}$ & $\begin{array}{l}\text { Pelaksanaan } \\
\text { Penelitian }\end{array}$ & $\begin{array}{l}\text { Pelaksanaan } \\
\text { Pengabdian } \\
\text { Masyarakat }\end{array}$ & \\
\hline 1 & $\begin{array}{l}\text { Asisten } \\
\text { Ahli }\end{array}$ & Magister & $\geq 55 \%$ & $\geq 25 \%$ & $\begin{array}{c}\text { Paling sedikit } \\
0,5 \mathrm{ak} \text { dan } \leq \\
10 \%\end{array}$ & $\leq 10 \%$ \\
\hline 2 & Lektor & Magister & $\geq 45 \%$ & $\geq 35 \%$ & $\begin{array}{c}\text { Paling sedikit } \\
0,5 \mathrm{ak} \text { dan } \leq \\
10 \%\end{array}$ & $\leq 10 \%$ \\
\hline 3 & $\begin{array}{l}\text { Lektor } \\
\text { Kepala }\end{array}$ & $\begin{array}{c}\text { Magister/Dokto } \\
\mathrm{r}\end{array}$ & $\geq 40 \%$ & $\geq 40 \%$ & $\begin{array}{c}\text { Paling sedikit } \\
0,5 \mathrm{ak} \mathrm{dan} \leq \\
10 \%\end{array}$ & $\leq 10 \%$ \\
\hline 4 & 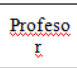 & Doktor & $\geq 35 \%$ & $\geq 45 \%$ & $\begin{array}{c}\text { Paling sedikit } \\
0,5 \mathrm{ak} \mathrm{dan} \leq \\
10 \%\end{array}$ & $\leq 10 \%$ \\
\hline
\end{tabular}

Tabel tersebut persentase penilaian angka kredit dosen dari kedua unsur utama maupun unsur penunjang.

\section{TINJAUAN PUSTAKA}

Penelitian yang membahas siklus sistem informasi eksekutif dapat menyajikan informasi pada manajamen puncak. Penyajian informasi ini dapat digunakan untuk memudahkan dalam pengambilan keputusan (Lungu, 2005). Informasi yang ditampilkan dapat dijadikan menjadi pertimbangan dalam menentukan strategi bagi kemajuan perguruan tinggi.

Penelitian terkait penerapan pendekatan siklus sistem informasi eksekutif sendiri telah dilakukan pada berbagai bidang diantaranya untuk menentukan kinerja civitas akademika (Indriyani, Seminar, et al., 2019). Penelitian tersebut menjelaskan dengan adanya penerapan sistem informasi eksekutif. Mutu penyelenggaraan pendidikan dan pengembangan karir profesi dosen dapat diketahui dengan mudah.

Penelitian yang menjelaskan pentingnya sistem informasi eksekutif bagi perguruan tinggi karena meningkatkan tingkat strategi yang diputuskan manakala sistem informasi eksekutif tersebut digunakan (Lungu \& Teodora, 2005).

Penelitian terkait sistem informasi eksekutif dengan tema evaluasi diri perguruan tinggi menghasilkan prototipe evaluasi diri yang mengintegrasikan sistem infomasi yang ada dengan menggunakan model arsitektur berorientasi layanan dengan pendekatan ekstraksi, transformasi data dan muat data tersebut pada sistem informasi eksekutif (Sopingi, 2015).

\section{HASIL DAN PEMBAHASAN}

\section{a. Proses ETL Sistem Informasi Kepegawaian}

Data yang dimuat pada sistem informasi eksekutif tri dharma perguruan tinggi berasal dari sistem informasi kepegawaian. Data hasil proses ETL Sistem Informasi Kepegawaian yaitu berupa NIDN, Nama Dosen, Jenjang Pendidikan dan penunjang yang diperoleh dengan perintah yang ditunjukan pada gambar berikut:

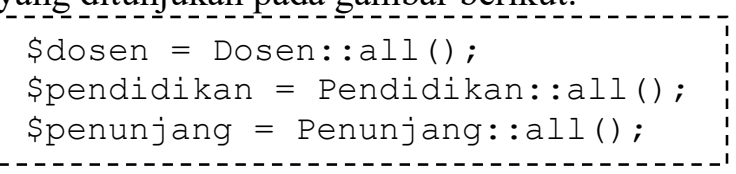

\section{Gambar 3. Proses ETL SIMPEG}

Rangkaian perintah yang ditunjukan pada gambar tersebutmenunjukan proses ETL yang dilakukan dari sistem informasi kepegawaian sebagai masukan pada sistem informasi eksekutif tri dharma.

\section{b. Proses ETL Sistem Informasi Lembaga \\ Penelitian dan Pengabdian Masyarakat}

Data yang dimuat pada sistem informasi eksekutif tri dharma perguruan tinggi berasal dari sistem informasi lembaga penelitian dan pengabdian masyarakat. Data hasil proses ETL Sistem Informasi LP2M yaitu berupa data penelitian dan data pengabdian kepada masyarakat yang diperoleh dengan perintah yang ditunjukan pada gambar dibawah ini:

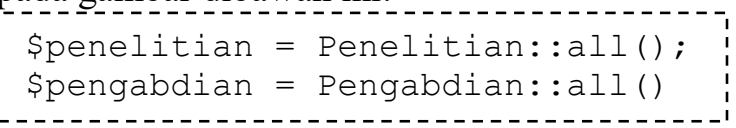

\section{Gambar 4. Proses ETL SIMLP2M}

Rangkaian perintah yang ditunjukan pada gambar tersebutmenunjukan proses ETL yang dilakukan dari sistem informasi lembaga penelitian dan pengabdian sebagai masukan pada sistem informasi eksekutif tri dharma.

\section{c. Proses ETL Sistem Informasi Akademik}

Data yang dimuat pada sistem informasi eksekutif tri dharma perguruan tinggi berasal dari sistem informasi akademik. Data hasil proses ETL Sistem Informasi akademik yaitu berupa data pengajaran dan penunjang yang diperoleh dengan perintah yang ditunjukan pada gambar dibawah ini:

Spengajaran = Pengajaran: :all ();

Gambar 5. Proses ETL SIAKAD 
Rangkaian perintah yang ditunjukan pada gambar tersebut menunjukan proses ETL yang dilakukan dari sistem informasi akademik sebagai masukan pada sistem informasi eksekutif tri dharma.

\section{d. Ringkasan Kinerja Tridharma Dosen}

Ringkasan tridharma dosen yang diperoleh dari halaman PAK ditunjukan pada tabel dan gambar berikut ini:

Tabel 2. Ringkasan tri dharma dosen

\begin{tabular}{|c|c|c|c|}
\hline $\begin{array}{c}\mathbf{N} \\
\mathbf{O}\end{array}$ & NIDN & $\begin{array}{c}\text { JABATAN } \\
\text { FUNGSIONAL }\end{array}$ & $\begin{array}{c}\text { TOTAL } \\
\text { KUM } \\
\text { AJUAN }\end{array}$ \\
\hline 1 & 0606066203 & 150 & 164 \\
\hline 2 & 0611016501 & 200 & 164 \\
\hline 3 & 0627049101 & 150 & 164 \\
\hline 4 & 0628037001 & 150 & 164 \\
\hline
\end{tabular}

Perancangan sistem informasi eksekutif tridharma perguruan tinggi menghasilkan laporan PAK yang ditunjukan pada tabel 2 . Informasi yang diperoleh berupa daftar pengusul jabatan fungsional.

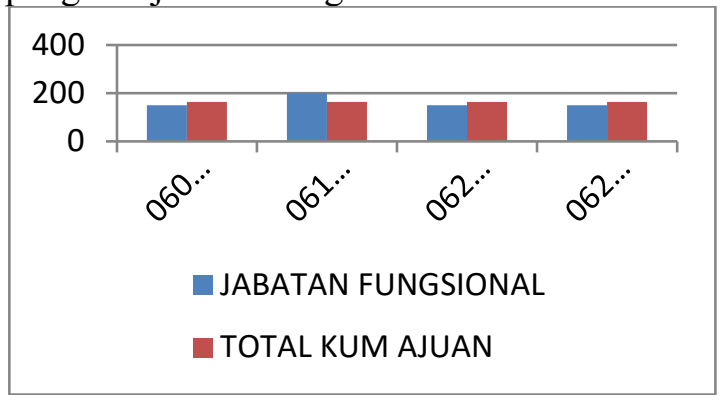

Gambar 6. Kinerja dosen

Grafik diatas menunjukan dari empat pengusul jabatan fungsional salah satu dosen pengusul mengusulkan jabatan fungsional lektor 200. Representasi grafis tersebut memudahkan dalam proses interpretasi manajemen puncak dalam mengetahui kinerja tridharma perguruan tinggi dengan menggunakan sistem informasi eksekutif tridharma perguruan tinggi.

\section{PENUTUP}

\section{a. Kesimpulan}

Penelitian ini menyimpulkan perancangan sistem informasi eksekutif tri dharma perguruan tinggi menghasilkan rancangan rumusan strategi promosi jabatan fungsional bagi dosen Universitas Duta Bangsa dengan Service Oriented Architecture.

b. Saran

Penelitian ini masih dalam tahap perancangan secara konseptual, dengan demikian diperlukan pengembangan lebih lanjut dimasa datang.

\section{REFERENSI}

Adiguna, M. A., \& Muhajirin, A. (2017). Penerapan Logika Fuzzy Pada Penilaian Mutu Dosen Terhadap Tri Dharma Perguruan Tinggi. Jurnal Online Informatika, 2(1), 16. https://doi.org/10.15575/join.v2i1.74

Anggadini, S. D. (2013). Analisis Sistem Informasi Manajemen Berbasis Komputer dalam Proses Pengambilan Keputusan. Majalah Ilmiah Unikom, 11(2), 176-187.

Bernadi, J., \& Suharjito. (2016). Executive Information System Modelling to Monitor Indonesia Criminal Rate. CommIT. https://doi.org/10.21512/ commit.v10i1.935

Heri Nurdiyanto, \& Envermy Vem. (2015). Performance Evaluation Decision Support System Using The Lecturer Analytical Hierarchy Process (Case Study: STMIK Dharma Wacana Metro). Tim Darmajaya.

ndriyani, Y. D., Seminar, K. B., \& Sukoco, H. (2019). Sistem Pendukung Informasi Eksekutif Mobilitas Sivitas Akademika dan Publikasi Ilmiah Institute Pertanian Bogor. Jurnal Pustakawan Indonesia.

Kurniasari, R. I., Dariyo, A., \& Idulfilastri, R. M. (2018). Hubungan Antara SelfEfficacy dengan Pengambilan Keputusan Karier pada Mahasiswa Tingkat Akhir Fakultas Psikologi. Journal An-Nafs: Kajian Penelitian Psikologi, 3(1), 1-19. https://doi.org/10.33367/psi.v3i1.497

Lungu, I., \& Bara, A. (2005). Executive information systems development lifecycle. Economy Informatics Review. https://doi.org/10.1109/MSIE.2011.5707 593

Lungu, I., \& Teodora, V. (2005). Executive Information Systems: Development Lifecycle and Building by Using The Business Inteligence Tools. 837-841.

Putra, A. B., Gemilang, C. C., Fajar, M. B., \& Ahmad Mustofa.K.Pasya. (2019). Sistem 
Informasi Eksekutif Stok Daging Sapi di Pulau Jawa. Prosiding Nasional Rekayasa Teknologi Industri Dan Informasi XIV.

Rubiono, G., \& Finahari, N. (2017). Dosen: Profil-profil Sederhana dalam Profesi yang Rumit. JAS-PT Jurnal Analisis Sistem Pendidikan Tinggi, 1(1), 11. https://doi.org/10.36339/jaspt.v1i1.35

Sopingi. (2015). Prototype Executive Information System untuk Mendukung Evaluasi Diri Perguruan Tinggi (Studi Kasus: STMIK Duta Bangsa Surakarta).

Suparno. (2018). Peran Kepemimpinan dalam Pengambilan Keputusan. Jurnal Untag Semarang.

Adiguna, M. A., \& Muhajirin, A. (2017). Penerapan Logika Fuzzy Pada Penilaian Mutu Dosen Terhadap Tri Dharma Perguruan Tinggi. Jurnal Online Informatika, $2(1), \quad 16$. https://doi.org/10.15575/join.v2i1.74

Anggadini, S. D. (2013). Analisis Sistem Informasi Manajemen Berbasis Komputer dalam Proses Pengambilan Keputusan. Majalah Ilmiah Unikom, 11(2), 176-187.

Bernadi, J., \& Suharjito. (2016). Executive Information System Modelling to Monitor Indonesia Criminal Rate. CommIT. https://doi.org/10.21512/ commit.v10i1.935

Heri Nurdiyanto, \& Envermy Vem. (2015). Performance Evaluation Decision Support System Using The Lecturer Analytical Hierarchy Process (Case Study: STMIK Dharma Wacana Metro). Tim Darmajaya.

Indonesia, R. (1961). Undang-Undang Republik Indonesia Nomor 22 Tahun 1961 tentang Perguruan Tinggi. Retrieved from http://www.ghbook.ir/index.php?name=

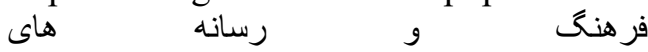
\& نوين\&option=com_dbook\&task=readonli ne\&book_id $=136 \overline{50}$ \&page $=73 \&$ chkhash $\mathrm{k}=$ ED9C9491B4\&Itemid $=218 \&$ lang $=\mathrm{fa}$ $\& \mathrm{tmpl}=$ component

Indonesia, R. (2003). Undang-Undang Republik Indonesia Nomor 20 Tahun 2003 tentang Sistem Pendidikan Nasional.

https://doi.org/10.16309/j.cnki.issn.10071776.2003.03.004
Indriyani, Y. D., Seminar, K. B., \& Sukoco, H. (2019). Sistem Pendukung Informasi Eksekutif Mobilitas Sivitas Akademika dan Publikasi Ilmiah Institute Pertanian Bogor. Jurnal Pustakawan Indonesia.

Kurniasari, R. I., Dariyo, A., \& Idulfilastri, R. M. (2018). Hubungan Antara SelfEfficacy dengan Pengambilan Keputusan Karier pada Mahasiswa Tingkat Akhir Fakultas Psikologi. Journal An-Nafs: Kajian Penelitian Psikologi, 3(1), 1-19. https://doi.org/10.33367/psi.v3i1.497

Lungu, I., \& Bara, A. (2005). Executive information systems development lifecycle. Economy Informatics Review. https://doi.org/10.1109/MSIE.2011.5707 593

Lungu, I., \& Teodora, V. (2005). Executive Information Systems: Development Lifecycle and Building by Using The Business Inteligence Tools. 837-841.

Putra, A. B., Gemilang, C. C., Fajar, M. B., \& Ahmad Mustofa.K.Pasya. (2019). Sistem Informasi Eksekutif Stok Daging Sapi di Pulau Jawa. Prosiding Nasional Rekayasa Teknologi Industri Dan Informasi XIV.

Rubiono, G., \& Finahari, N. (2017). Dosen: Profil-profil Sederhana dalam Profesi yang Rumit. JAS-PT Jurnal Analisis Sistem Pendidikan Tinggi, 1(1), 11. https://doi.org/10.36339/jaspt.v1i1.35

SAS. (2019). ETL. Retrieved from https://www.sas.com/en_id/insights/datamanagement/what-is-etl.html

Sopingi. (2015). Prototype Executive Information System untuk Mendukung Evaluasi Diri Perguruan Tinggi (Studi Kasus: STMIK Duta Bangsa Surakarta).

Suparno. (2018). Peran Kepemimpinan dalam Pengambilan Keputusan. Jurnal Untag Semarang.

Sutrisna Wibawa. (2017). Tridharma-Pt-Itjen1.

Suyudi, Djuliansah, D., \& Nuryaman, H. (2016). Teknik/Teori Pengambilan Keputusan.

Tarigan S, I. Y. S., Soedjatmiko, S., \& Hartanto, R. (2010). Perancangan Basis Data dan Layanan Akses Berbasis Service Oriented Architecture (SOA) Untuk Dinas Kesehatan Kabupaten Sleman. Jurnal Buana Informatika, 1(1), 15-28. https://doi.org/10.24002/jbi. v1i1.293. 